\title{
PRIMARY CENTRAL NERVOUS SYSTEM EFFUSION PLASMABLASTIC LYMPHOMA IN IMMUNOCOMPROMISED PATIENT: A RARE PHENOMENON
}

\author{
BRIJ MOHAN SINGH ${ }^{1 *}$, SUSHMA BELURKAR ${ }^{1}$, ARIJIT BISHNU ${ }^{2}$, TANVI SHETTY ${ }^{2}$, PAVITHRA P ${ }^{2}$
}

${ }^{1}$ Department of Pathology, Kasturba Medical College, Manipal Academy of Higher Education, Manipal - 576 104, Karnataka, India. ${ }^{2}$ Department of Pathology, Melaka Manipal Medical College, Manipal Academy of Higher Education, Manipal - 576 104, Karnataka, India. Email: brij.singh@manipal.edu

Received: 13 January 2018, Revised and Accepted: 10 May 2018

ABSTRACT

Primary effusion lymphoma (PEL) is an aggressive neoplasm with a high rate of fatality. PEL cells are known to have morphological diversities, which range from immunoblastic or plasmablastic to anaplastic. Most of these cases are described in immunocompromised as well as immunocompetent patients. Plasmablastic lymphoma remains a diagnostic challenge, especially when encountered with the presentation as PEL. In spite of therapeutic advances, PEL remains an aggressive disease with a high rate of fatality. We describe one case of this extremely rare neoplasm in an immunocompromised patient presenting in the form of primary central nervous system effusion plasmablastic lymphoma. To the best of our knowledge, this is the first case ever been reported in the literature.

Keywords: Primary effusion lymphoma, Plasmablastic lymphoma, Papanicolaou smear, Flow cytometry.

(C) 2018 The Authors. Published by Innovare Academic Sciences Pvt Ltd. This is an open access article under the CC BY license (http://creativecommons. org/licenses/by/4. 0/) DOI: http://dx.doi.org/10.22159/ajpcr.2018.v11i8.24754

\section{INTRODUCTION}

Cancer is the most dreaded disease of the $21^{\text {st }}$ century, and the frequency of its occurrence in adults is 2.7 times more than in children and lymphomas contribute to almost 18\% [1]. Infection with human immunodeficiency virus (HIV) predisposes to the development of neoplasm including lymphoma [2,3]. Primary effusion lymphoma is one of the least common of the AIDS-related lymphomas, accounting for $1-4 \%$ of all cases $[4,5]$. Plasmablastic lymphoma (PBL) is a rare subtype of diffuse large B-cell lymphoma associated with HIV patients. Its presentation as primary central nervous system (CNS) effusion lymphomas is even rarer, in which there is no detectable tumor in the individual.

\section{CASE REPORT}

A 45-year immunocompromised male, presented to the neurosurgery department of Kasturba Hospital with complaint of headache, and altered sensorium for 15 days with no fever, neck rigidity, weight loss, organomegaly, or lymphadenopathy. Both plain computed tomography and magnetic resonance imaging of the brain yielded essentially normal findings. Papanicolaou-stained smears of cerebrospinal fluid (CSF) from the patients were examined. The smears showed increased cellularity with flourishing abnormal plasmacytoid cells (Fig. 1). Immunohistochemistry was attempted on cell block but was not processed due to scanty cell yield. Flow cytometry on fresh CSF sample was performed. The neoplastic cells showed plasmacytic differentiation with expression of bright CD38 and CD56 in approximately 67-70\% of the total cells. These cells were also negative for CD79a and CD19. Interestingly, the neoplastic cells were not restricted for both kappa and lambda light chain, signifying non-secretory phenotype. Protein electrophoresis showed a normal pattern.

\section{DISCUSSION}

PBL is a rare phenotype presenting as primary CNS effusion lymphoma. To the best of our knowledge, till date, there is no reference in the literature of this type of presentation of PBL. PBL is known as one of the most aggressive forms of lymphoma and now has been accepted by the WHO as one of the subtypes of diffuse large B-cell lymphoma [6]. Since the first description of PBL, in 1997, by Delecluse et al. [7], the spectrum of PBL involvement of various organs has widened. Various sites from where it has been reported include skin [8], breast [9], gastrointestinal [10], central nervous system [11], male genitourinary system, and bone [12]. It is rarely found in children [13]. PBL is characterized by B-immunoblastlike cells with the expression of immunophenotype as explained in mature plasma cells [14]. Morphologically, PBL cells have two subtypes described in literature [15], first, which is most common is characterized by monomorphic neoplastic cells with minimal or no plasmacytic differentiation. The second type includes PBL with plasmacytic differentiation which shows tumor cells with differentiation to mature plasma cells, i.e., round-to-oval cells with an eccentric nucleus and some with prominent nucleolus. Sometimes, a very conspicuous perinuclear hof in the cytoplasm may be seen [16]. Epstein-Barr Virus, a human gamma herpesvirus, infects almost $90 \%$ of population worldwide and is associated with the development of B-cell lymphomas [17]. It is also found in most of the plasmablastic cases, whereas human herpesvirus 8 (HHV8) is absent [18]. We were unable to go further with immunology for Epstein-Barr virus or HHV8 as the patient was lost to follow-up.

\section{CONCLUSION}

Primary CNS effusion lymphoma of non-secretory plasmablastic type is the rarest phenomenon to be reported in the literature. When there is an established hematological or solid organ malignancy, the abnormal CSF cells can be easily subcategorized, but for a primary CNS effusion lymphoma, concurrent flow cytometry, and cytomorphological evaluation are the most appropriate to come to an acceptable conclusion.

\section{AUTHOR'S CONTRIBUTION}

Dr. Brij Mohan: Interpretation of cytomorphology and case report write up and has reviewed the article. Dr. Sushma: Interpretation of flow cytometry. Dr. Arijit: Extracting the case file with other case details. Dr. Tanvi: Write up and also reviewed the article. Dr. Pavithra: Reviewing literature for the occurrence of the case. 


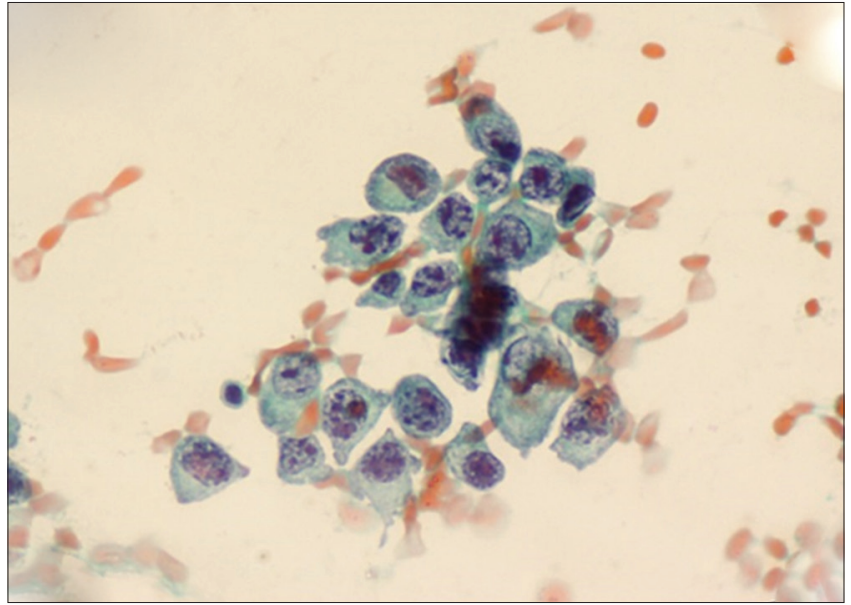

Fig. 1: Papanicolaou stain $(\times 400)$ cerebrospinal fluid smear showing bizarre plasmacytoid cells

\section{CONFLICTS OF INTEREST}

The authors declare that they have no conflicts of interest.

\section{REFERENCES}

1. Parmar F, Kushawaha N, Highland H, George LB. In vitro antioxidant and anticancer activity of Mimosa pudica Linn extract and 1-mimosine on lymphoma Daudi cells. Int J Pharm PharmSci 2015;7:100-4

2. Sandler AS, Kaplan LD. Diagnosis and management of systemic nonHodgkin's lymphoma in HIV disease. Hematol Oncol Clin North Am 1996;10:1111.

3. Coté TR, Biggar RJ, Rosenberg PS, Devesa SS, Percy C, Yellin FJ, et al. Non-hodgkin's lymphoma among people with AIDS: Incidence, presentation and public health burden. AIDS/Cancer study group. Int J Cancer 1997;73:645-50.

4. Wang CC, Kaplan LD. Clinical management of HIV-associated hematologic malignancies. Expert Rev Hematol 2016;9:361.

5. Simonelli C, Spina M, Cinelli R, Talamini R, Tedeschi R, Gloghini A, et al. Clinical features and outcome of primary effusion lymphoma in HIV-infected patients: A single-institution study. J Clin Oncol 2003;21:3948-54.
6. Jaffe ES, Harris NL, Stein H, Vardiman JW, editors. World Health Organization (WHO) Classification of Tumors. Pathology and Genetics of Tumours of Haematopoietic and Lymphoid Tissue. Lyon, France: IARC Press; 2009. p. 256-7.

7. Delecluse HJ, Anagnostopoulos I, Dallenbach F, Hummel M, Marafioti T, Schneider U, et al. Plasmablastic lymphomas of the oral cavity: A new entity associated with the human immunodeficiency virus infection. Blood 1997;89:1413-20.

8. Dales JP, Harket A, Bagnères D, Andrac-Meyer L, Xerri L, Frances Y, et al. Plasmablastic lymphoma in a patient with HIV infection: An unusual case located in the skin. Ann Pathol 2005;25:45-9.

9. Liang R, Wang Z, Chen XQ, Bai QX. Treatment of plasmablastic lymphoma with multiple organ involvement. Singapore Med J 2014;55:e194-7.

10. Huang X, Zhang Y, Gao Z. Plasmablastic lymphoma of the stomach with C-MYC rearrangement in an immunocompetent young adult: A case report. Medicine (Baltimore) 2015;94:e470.

11. Romero M, González-Fontal GR, Saavedra C, Guerra J, Quintero G, Quijano S, et al. Primary CNS plasmablastic lymphoma in an HIV/ EBV negative patient: A case report. Diagn Cytopathol 2016;44:61-5.

12. Schichman SA, McClure R, Schaefer RF, Mehta P. HIV and plasmablastic lymphoma manifesting in sinus, testicles, and bones: A further expansion of the disease spectrum. Am J Hematol 2004;77:291-5.

13. Vasudevan G, Singh BM, Bishnu A, Kulshreshta A. Plasmablastic lymphoma: A report of 2 cases with review of literature. J Interdiscipl Histopathol 2016;4:74-8.

14. Stein H, Harris NL, Campo E. Plasmablastic lymphoma. In: Swerdlow SH, Campo E, Harris NL, Jaffe ES, Pileri SA, Stein H, et al. editors. WHO Classification of Tumours of Haematopoietic and Lymphoid Tissues. $4^{\text {th }}$ ed. Lyon: IARC Press; 2008. p. 256-7.

15. Colomo L, Loong F, Rives S, Pittaluga S, Martínez A, LópezGuillermo A, et al. Diffuse large B-cell lymphomas with plasmablastic differentiation represent a heterogeneous group of disease entities. Am J Surg Pathol 2004;28:736-47.

16. Castillo JJ, Reagan JL. Plasmablastic lymphoma: A systematic review. Sci World J 2011;11:687-96

17. Malathi J, Janani MK, Murugan N, Madhavan HN. Draft genome sequence of human herpes virus-4 VRF_EBV_01, an Epstein Barr virus obtained from a pediatric post-transplant lymphoproliferative disorder (PTLD) patient. Int J Pharm PharmSci 2015;7:513-4.

18. Kim Y, Park CJ, Roh J, Huh J. Current concept in primary effusion lymphoma and other effusion-based lymphoma. Korean J Pathol 2014;48:81-90. 